\title{
Subcritical water extraction to isolate kinetically different soil nitrogen fractions
}

\author{
S. Sleutel ${ }^{1}$, M. A. Kader ${ }^{1,2}$, K. Demeestere ${ }^{3}$, C. Walgraeve ${ }^{3}$, J. Dewulf ${ }^{3}$, and S. De Neve ${ }^{1}$ \\ ${ }^{1}$ Department of Soil Management, Ghent University, Coupure Links 653, 9000 Gent, Belgium \\ ${ }^{2}$ Department of Soil Science, Bangladesh Agricultural University, Mymensingh 2202, Bangladesh \\ ${ }^{3}$ Department of Sustainable Organic Chemistry and Technology, Research Group EnVOC, Ghent University, \\ Coupure Links 653, 9000 Gent, Belgium
}

Correspondence to: S. Sleutel (steven.sleutel@UGent.be)

Received: 2 May 2013 - Published in Biogeosciences Discuss.: 17 June 2013

Revised: 18 September 2013 - Accepted: 27 September 2013 - Published: 19 November 2013

\begin{abstract}
Soil organic N is largely composed of inherently biologically labile proteinaceous $\mathrm{N}$ and its persistence in soil is mainly explained by stabilization through binding to minerals and other soil organic matter (SOM) components at varying strengths. In order to separate kinetically different soil $\mathrm{N}$ fractions we hypothesize that an approach which isolates soil $\mathrm{N}$ fractions on the basis of bonding strength is required, rather than employing chemical agents or physical methods. We developed a sequential subcritical water extraction (SCWE) procedure at 100,150 and $200^{\circ} \mathrm{C}$ to isolate SOM fractions. We assessed these SCWE N fractions as predictors for aerobic and anaerobic $\mathrm{N}$ mineralization measured from 25 paddy soil cores in incubations. SCWE organic carbon (SCWE OC) and N (SCWE N) increased exponentially with the increase of temperature and $\mathrm{N}$ was extracted preferentially over OC. The efficiency of SCWE and the selectivity towards $\mathrm{N}$ were both lower in soils with increasingly reactive clay mineralogy. Stepwise linear regression found no relations between the SCWE fractions and the anaerobic $\mathrm{N}$ mineralization rate but instead with $\mathrm{pH}$ and a model parameter describing the temperature dependency of SCWE extraction. Both were linked to texture, mineralogy and content of pedogenic oxides, which suggests an indirect relation between anaerobic $\mathrm{NH}_{4}^{+}$release and these edaphic soil factors. $\mathrm{N}$ mineralization appeared to be largely decoupled from SOM quantity and quality. From the present study on young paddy soils low in pedogenic oxides and with high fixed $\mathrm{NH}_{4}^{+}$content we cannot infer the performance of SCWE to isolate bio-available $\mathrm{N}$ in more developed upland soils. There may be potential to separate kinetically different SOM pools
\end{abstract}

from upland soils because $1^{\circ}$ for aerobic $\mathrm{N}$ mineralization at $100-150^{\circ} \mathrm{C}$ SCWE $\mathrm{N}$ was the best predictor; and $2^{\circ} \mathrm{SCWE}$ selectively extracted $\mathrm{N}$ over $\mathrm{C}$ and this preference depended on the mineralogical composition. Hence $\mathrm{N}$ fractions differing in bonding strength with minerals or SOM might be isolated at different temperatures, and specifically this association has frequently been found a prominent stabilization mechanism of $\mathrm{N}$ in temperate region cropland soils.

\section{Introduction}

Mineralization of soil organic nitrogen $(\mathrm{N})$ remains a significant source of mineral $\mathrm{N}$ in paddy rice cultivation despite the widespread use of inorganic $\mathrm{N}$ fertilizers and organic $\mathrm{N}$ sources. Strikingly, often poor correlations were found between $\mathrm{N}$ mineralization in the field and general soil properties like $\mathrm{N}$ or organic carbon (OC) content and the soil's $\mathrm{C}: \mathrm{N}$ ratio or a combination of those factors with $\mathrm{pH}$, cation exchange capacity, clay content, etc. (Sahrawat, 1983a, b, 2006, 2010; Ros et al., 2011). Instead, successful indices to predict paddy soil's $\mathrm{N}$ supplying capacity include $\mathrm{N}$ uptake by plants (Sahrawat, 1983a; Nayyar et al., 2006; Curtin and McCallum, 2004) or measurement of increases in soil inorganic N upon incubation (Augus et al., 1994; Mikha et al., 2006). Yet, such "reference" biological methods are time-consuming and expensive with little significance for in-time fertilizer recommendation. Consequently, a multitude of simple and rapid chemical indices of paddy soil's $\mathrm{N}$ supplying capacity have been tested. For example, recently, 
Li et al. (2011) found that the soil's $\mathrm{C}: \mathrm{N}$ ratio, acid $\mathrm{KMnO}_{4}$ $\mathrm{NH}_{4}^{+}-\mathrm{N}$, alkaline $\mathrm{KMnO}_{4}-\mathrm{NH}_{4}^{+}-\mathrm{N}$, phosphate-borate buffer extractable $\mathrm{NH}_{4}^{+}-\mathrm{N}$, phosphate-borate buffer hydrolysable $\mathrm{NH}_{4}^{+}-\mathrm{N}$ and hot $\mathrm{KCl}$ extractable $\mathrm{NH}_{4}^{+}-\mathrm{N}$ were all significantly $(P<0.05)$ correlated to total $\mathrm{N}$ uptake by rice plants. However, the relation between such chemical soil $\mathrm{N}$ fractions and $\mathrm{N}$ supplying processes actually occurring in the soil is weak and chemical approaches do not represent physical aspects of bio-availability of N. For instance, physical occlusion of particulate organic matter in microaggregates slows its microbial consumption (e.g. Six et al., 2000). In addition, soil structure controls microbial community structure and thereby indirectly determines soil $\mathrm{N}$ supply. For example, in soil with a larger proportion of $15-30 \mu \mathrm{m}$ pore necks, Sleutel et al. (2011) found a promotion of fungi over bacteria. Since both decomposer groups have differing $C: N$ ratios and $\mathrm{N}$ requirements, variation in microbial community structure logically results in differing utilization of $\mathrm{OM}$ and in mineral $\mathrm{N}$ release. In addition, chemical extractions generate artefacts, e.g. acid hydrolysis, aimed at removing labile organic matter, also liberates mineral bound OM by dissolution of Fe oxides at low pH (Kögel-Knabner et al., 2008). As a result, the development of a single chemical $\mathrm{N}$ index that is applicable to many types of soils, crops, and locations has not been successful (Wilson et al., 1994). In fact from an extensive meta-analysis Ros et al. (2011) concluded that the relationship between extractable $\mathrm{OM}$ and soil $\mathrm{N}$ supply is mostly an indirect relationship reflecting the soil's OM content.

Organic $\mathrm{N}$ is largely composed of inherently biologically labile proteinaceous $\mathrm{N}$ ranging between $40 \%$ (Schulten and Schnitzer, 1998) and $80 \%$ (Knicker, 2000), and a smaller share is present as heterocyclic N. Persistence of soil $\mathrm{N}$ is primarily explained by stabilization through binding to minerals and other SOM components and Leinweber and Schulten (2000), for example, revealed a substantial part of proteinaceous and heterocyclic $\mathrm{N}$ to be selectively bound to pedogenic oxides. Appelqvist et al. (1996), in addition, demonstrated linkages between amino acids and humic acids and based on extensive molecular modelling Schulten and Schnitzer (1997) suggested that proteinaceous materials can be trapped in the voids of the three-dimensional structure of humic substances. In an alternative view on the physicochemical organization of soil organic matter, Kleber et al. (2007) instead hypothesized that proteinaceous $\mathrm{N}$ is enriched close to mineral surfaces and shielded by an outer zone of more hydrophobic SOM constituents. Regardless of the conceptual model, variation in strength of $\mathrm{N}$-mineral and $\mathrm{N}-\mathrm{OM}$ linkages is likely to determine variation in bioavailability of organic $\mathrm{N}$ and susceptibility to mineralization. Physical fractionation methods are limited in their ability to further subdivide this continuum of bound organic N, because of practical constraints to subdivide the clay size fraction which, however, does contain the majority of soil
$\mathrm{N}$. Therefore an alternative approach, which isolates soil $\mathrm{N}$ fractions on the basis of bonding strength may be required, ideally then with respect to dissolvability into water instead of size or density or solubility in chemical agents. In addition, the release of "fixed" $\mathrm{NH}_{4}^{+}$is often an important crop supply of mineral $\mathrm{N}$ in paddy soils (Schneiders and Scherer, 1998), next to $\mathrm{N}$ mineralization. It has become clear that there also exists a continuum in the bio-availability of fixed $\mathrm{NH}_{4}^{+}$(Nieder et al., 2011), which is linked to its association with soil minerals. Commonly, a distinction is made between "native fixed" and "recently fixed" $\mathrm{NH}_{4}^{+}$, where the former is probably trapped in the centre of clay interlayers to a higher degree, while the latter pool is largely retained in the peripheral zone of the interlayers (Nommik and Vahtras, 1982).

We hypothesize that soil $\mathrm{N}$ extracted by water at increasing temperatures would reflect organic and inorganic $\mathrm{N}$ fractions with increasing bonding strength, which in turn should correspond to decreasing bio-availability. Indeed, Kalbitz et al. (2005) amongst others concluded that strength of sorption reflects stability of the sorbed OM against biodegradation. Although water has frequently been used to quantify labile N or plant available N (e.g. Chantigny et al., 2010; and Curtin et al., 2006) or labile C (Sparling et al., 1998; Ghani et al., 2003) extraction of SOM has most often been limited to a temperature of $100^{\circ} \mathrm{C}$ due to the difficulties of keeping it in a liquid state above $100^{\circ} \mathrm{C}$. This has limited the potential of water extraction to the isolation of readily bio-available SOM. Accelerated solvent extractors now conveniently offer the ability to extract soil samples with solvents at higher temperatures. By raising the inner pressure in metal extraction cells containing the soil sample, subcritical $\left(100-375^{\circ} \mathrm{C}\right)$ and supercritical $\left(>375^{\circ} \mathrm{C}\right)$ water have been used to extract a variety of organic compounds from solid matrixes for chemical analysis (Ong et al., 2006; Lagadec et al., 2000). To our knowledge, SOM extraction by subcritical water has only been tested by Schnitzer et al. (1991) on four Canadian soils and recently, a custom-built instrument was developed for biomarker extraction in upcoming Mars explorer missions (Amashukeli et al., 2008). There appears to be no published information on the relation between subcritical water extractible $\mathrm{N}$ and $\mathrm{OC}$ and soil $\mathrm{N}$ mineralization. In the present study we developed a sequential subcritical water extraction (SCWE) procedure at 100,150 and $200^{\circ} \mathrm{C}$ to isolate SOM fractions from 25 paddy soil samples and we investigated how clay content and mineralogy affected extractability of $\mathrm{N}$ and C. Our main objective was to investigate the potential of SCWE $\mathrm{N}$ fractions to predict aerobic and anaerobic paddy soil $\mathrm{N}$ mineralization. 


\section{Materials and methods}

\subsection{Soils}

A set of 25 paddy soils was previously collected (Kader et al., 2013) from agricultural fields throughout northern Bangladesh, which has a subtropical monsoon climate (annual mean temperature of $25.8^{\circ} \mathrm{C}$ and annual precipitation of $2428 \mathrm{~mm}$; Bangladesh Meteorological Department, 2011). Either one or two rice crops were cultivated per year on the sampled fields. Surface soil samples $(0-15 \mathrm{~cm})$ were collected from 15 locations per field by means of an auger (diameter $2.5 \mathrm{~cm}$ ). These samples were bulked into one composite sample and were thoroughly mixed. The field's moist soil was gently broken apart by hand, air dried and ground to pass a $2 \mathrm{~mm}$ sieve prior to further analysis.

\subsection{Analysis of soil properties, $\mathrm{N}$ mineralization and clay mineralogy}

Soil texture, soil $\mathrm{C}$ and $\mathrm{N}$ content, $\mathrm{pH}$ in $\mathrm{KCl}\left(\mathrm{pH}_{\mathrm{KCl}}\right), \mathrm{NH}_{4}$ oxalate extractable $\mathrm{Fe}, \mathrm{Al}$ and $\mathrm{Mn}\left(\mathrm{Fe}_{\mathrm{ox}}, \mathrm{Al}_{\mathrm{ox}}, \mathrm{Mn}_{\mathrm{ox}}\right)$ were determined on all 25 soils by Kader et al. (2013) (Table 1). Briefly, the soil texture of the collected soil samples ranged from sand to clay with most soils being silt loams. With an average $\mathrm{pH}_{\mathrm{KCl}}$ of 4.5 , all soils were moderately acidic (Table 1). There were wide ranges in $\mathrm{C}$ and $\mathrm{N}$ content with averages of $14.40 \pm 7.14 \mathrm{~g} \mathrm{C} \mathrm{kg}^{-1}$ and $1.48 \pm 0.66 \mathrm{~g} \mathrm{~N} \mathrm{~kg}^{-1}$. Ammonium oxalate extractable $\mathrm{Fe}$ also varied widely (1.1$8.3 \mathrm{~g} \mathrm{Fe} \mathrm{kg}^{-1}$ ), while variation in $\mathrm{Al}_{\mathrm{Ox}}$ and $\mathrm{Mn}_{\mathrm{Ox}}$ was limited.

Fixed $\mathrm{NH}_{4}^{+}$was determined by the Silva and Bremner method (Silva and Bremner, 1966), which consists of two steps. First, oxidation by alkaline $\mathrm{KOBr}$ removes exchangeable $\mathrm{NH}_{4}^{+}$and organic $\mathrm{N}$. Then treatment with a $5 \mathrm{~N} \mathrm{HF}-1 \mathrm{~N}$ $\mathrm{HCl}$ solution dissolves clay containing fixed $\mathrm{NH}_{4}^{+}$. The $\mathrm{NH}_{4}^{+}$ released by the $\mathrm{HF}-\mathrm{HCl}$ treatment was then determined by steam distillation.

$\mathrm{N}$ mineralization was assessed earlier by Kader et al. (2013) by monitoring the release of $\mathrm{NH}_{4}$ and $\mathrm{NO}_{3}$ under controlled aerobic and anaerobic conditions. Briefly, for each soil $42 \mathrm{PVC}$ tubes $(5 \mathrm{~cm}$ diameter) were filled with $200 \mathrm{~g}$ of dry soil, 21 ( 3 replicates $\times 7$ dates) for aerobic and 21 (3 replicates $\times 7$ dates) for anaerobic incubation. Soil moisture content was brought to $50 \%$ water filled pore space for assessment of aerobic $\mathrm{N}$ mineralization and soils were oversaturated with a standing water level of $2 \mathrm{~cm}$ for assessment of anaerobic $\mathrm{N}$ mineralization. Every two weeks, soils were sampled destructively by removing the soil from one tube per replicate. The aerobic $\mathrm{N}$ mineralization rates were estimated by fitting a zero-order kinetic model to the soil mineral $\mathrm{N}$ data: $N(t)=N_{0}+k_{0} t$, where $t$ is the time (in days), $N(t)$ is the amount of mineral $\mathrm{N}$ at time $t, N_{0}$ is the initial amount of mineral $\mathrm{N}\left(\mathrm{mg} \mathrm{N} \mathrm{kg}^{-1}\right)$, and $k_{0}$ is the linear $\mathrm{N}$ mineralization rate $\left(\mathrm{mg} \mathrm{N} \mathrm{kg}^{-1} \mathrm{day}^{-1}\right)$. The anaerobic $\mathrm{N}$ mineralization data were best described with a first-order model:
$N(t)=N_{\mathrm{A}}\left(1-\exp \left(-k_{1} t\right)\right)$, with $N_{\mathrm{A}}$ the mineralizable $\mathrm{N}$ and $k_{1}$ a first-order rate parameter.

The clay fraction's mineralogical composition was identified by X-ray diffraction on oriented samples after (i) $\mathrm{K}$ and $\mathrm{Mg}$ saturation, (ii) glycerol solvation, and (iii) drying of the $\mathrm{K}$ saturated samples at 300 and $550^{\circ} \mathrm{C}$ for $2 \mathrm{~h}$, as described in detail by Kader et al. (2013).

\subsection{Subcritical water extraction}

Soils were sequentially extracted with pressurized $(10,3-$ $11,7 \mathrm{MPa}$ ) liquid water at 100,150 and $200^{\circ} \mathrm{C}$ with an ASE 350 Accelerated Solvent Extractor (Dionex, Amsterdam, the Netherlands). The extraction residue at each temperature step was utilized for the next extraction, so that the 150 and $200^{\circ} \mathrm{C}$ extracts exclude the $100^{\circ} \mathrm{C}$ and $100+150^{\circ} \mathrm{C}$ extractable material respectively. We limited the upper extraction temperature to $200^{\circ} \mathrm{C}$ as, previously, Schnitzer et al. (1991) found rapid thermal degradation of SOM components around $250^{\circ} \mathrm{C}$. Soil samples of $7 \mathrm{~g}$ were mixed with acid washed sand at a $1: 2$ weight ratio in $22 \mathrm{~mL}$ capacity Dionex stainless steel extraction cells (equipped with PEEK seal ring and Viton O-rings) to achieve an adequate permeability for perfusion of the subcritical water. Quartz filters $(27 \mathrm{~mm})$ were fitted at the bottom and top of each cell. Each extraction cycle consisted of different steps: filling of the cell with water, heating, stationary extraction (static cycle time: 5 min, number of static cycles: 1), rinsing the cell with fresh deionized water (rinsing volume $60 \%$ ), and finally purging $(80 \mathrm{~s})$ with $\mathrm{N}_{2}$ gas. The extracts were collected in $60 \mathrm{~mL}$ glass vials and their volumes were determined by weight difference with the empty vials. At the end of the sequential extractions, the solid residues were removed from the cells and were oven dried at $105^{\circ} \mathrm{C}$ (Fig. 1). Subcritical water extractions were carried out in twofold.

\subsection{Carbon and nitrogen analysis}

Total OC in the subcritical water extracts was determined with a Shimadzu TOC-V analyser (Shimadzu Corp., Tokyo, Japan) with IR detection following thermal oxidation. Total $\mathrm{N}$ concentrations in the extracts were determined with the alkaline persulfate oxidation method (Koroleff, 1983). Produced $\mathrm{NO}_{3}-\mathrm{N}$ and $\mathrm{NO}_{3}-\mathrm{N}$ already present prior to persulfate oxidation was measured with a continuous flow autoanalyser (ChemLab System 4). Capped $10 \mathrm{ml}$ test vials, used as reaction vessels for persulfate oxidation, were centrifuged at $2000 \mathrm{rpm}$ prior to continuous flow analysis. The OC and N content of the dried SCWE residues were determined by elemental analysis (Variomax CNS analyser, Elementar Analysesysteme, Germany). $\mathrm{C}$ and $\mathrm{N}$ expressed in $\mathrm{g} \mathrm{kg}^{-1}$ present in the different SCWE fractions were calculated taking into account their of $\mathrm{N}$ and $\mathrm{C}$ contents, the extract volumes and the dry matter weight of the extracted residues. 
Table 1. Soil properties of sampled agricultural fields in Bangladesh (data from Kader et al., 2013).

\begin{tabular}{|c|c|c|c|c|c|c|c|c|c|c|c|c|c|c|}
\hline & \multirow[t]{2}{*}{$\begin{array}{l}\text { Soil } \\
\text { series }\end{array}$} & \multirow[t]{2}{*}{$\begin{array}{l}\text { Soil } \\
\text { type }\end{array}$} & \multirow[t]{2}{*}{$\begin{array}{l}\text { Cropping } \\
\text { pattern* }\end{array}$} & \multicolumn{3}{|c|}{$\begin{array}{l}\text { Soil particles } \\
(\%)\end{array}$} & \multirow{2}{*}{$\begin{array}{r}\text { Soil } \\
\text { OC } \\
\left(\mathrm{g} \mathrm{kg}^{-1}\right)\end{array}$} & \multirow{2}{*}{$\begin{array}{r}\text { Soil } \\
N \\
\left(\mathrm{~g} \mathrm{~kg}^{-1}\right)\end{array}$} & \multirow{2}{*}{$\begin{array}{r}\mathrm{C}: \mathrm{N} \\
\text { ratio } \\
(-)\end{array}$} & \multirow[t]{2}{*}{$\begin{array}{r}\mathrm{pH}_{\mathrm{KCl}} \\
(-)\end{array}$} & \multirow{2}{*}{$\begin{array}{r}\text { Fixed- } \\
\mathrm{NH}_{4}^{+} \\
\left(\mathrm{g} \mathrm{kg}^{-1}\right)\end{array}$} & \multicolumn{3}{|c|}{$\begin{array}{c}\mathrm{NH}_{4} \text {-oxalate } \\
\text { extractable }\left(\mathrm{g} \mathrm{kg}^{-1}\right)\end{array}$} \\
\hline & & & & $\begin{array}{r}>50 \\
\mu \mathrm{m}\end{array}$ & $\begin{array}{r}2-50 \\
\mu \mathrm{m}\end{array}$ & $\begin{array}{l}<2 \\
\mu \mathrm{m}\end{array}$ & & & & & & $\mathrm{Fe}_{\mathrm{ox}}$ & $\mathrm{Al}_{\mathrm{OX}}$ & $\mathrm{Mn}_{\mathrm{OX}}$ \\
\hline 1 & Sonatala-1 & Aeric Haplaquepts & R-F-R & 4 & 76 & 20 & 21.4 & 2.1 & 10.4 & 5.6 & 0.22 & 5.1 & 0.9 & 0.4 \\
\hline 2 & Sonatala-2 & Aeric Haplaquepts & R-F-R & 13 & 73 & 14 & 16.3 & 1.7 & 9.6 & 5.2 & 0.21 & 4.9 & 0.8 & 0.3 \\
\hline 3 & Faridgonj & Aeric Haplaquepts & R-F-R & 14 & 79 & 7 & 11.4 & 1.2 & 9.5 & 5.3 & - & 2.2 & 0.6 & 0.2 \\
\hline 4 & Noakhali & Arents & V-V-R & 9 & 79 & 12 & 10.0 & 1.1 & 9.4 & 5.7 & - & 2.9 & 0.7 & 0.1 \\
\hline 8 & Silmondi-1 & Aeric Haplaquepts & R-R/F-R & 14 & 59 & 27 & 16.4 & 1.6 & 10.1 & 5.5 & 0.13 & 4.1 & 0.7 & 0.2 \\
\hline 10 & Ghatail & Aeric Haplaquepts & $\mathrm{R}-\mathrm{R} / \mathrm{F}-\mathrm{F}$ & 9 & 41 & 50 & 21.2 & 2.2 & 9.4 & 4.9 & 0.32 & 4.5 & 1.1 & 0.1 \\
\hline 11 & Balina & Mollic Haplaquepts & R-F-F & 17 & 48 & 35 & 15.3 & 1.9 & 7.9 & 4.9 & 0.33 & 7.3 & 0.9 & 0.6 \\
\hline 12 & Melandoho & Aeric Fluvaquents & R-F-R & 21 & 63 & 16 & 8.2 & 0.9 & 8.8 & 3.9 & 0.16 & 3.3 & 0.6 & 0.2 \\
\hline 13 & Tarakanda & Typic Fluvaquents & F-F-R & 78 & 14 & 8 & 3.9 & 0.4 & 9.5 & 4.0 & 0.05 & 1.1 & 0.2 & 0.1 \\
\hline 15 & Gorargao & Typic Haplaquepts & R-F-F & 18 & 39 & 43 & 30.5 & 3.2 & 9.6 & 4.6 & 0.26 & 3.7 & 1.2 & 0.2 \\
\hline 16 & Noadda-1 & Ultic Ustochrepts & F-F-R & 10 & 46 & 44 & 9.2 & 1.0 & 9.1 & 3.7 & 0.15 & 6.1 & 0.9 & 0.2 \\
\hline 19 & Dhamrai & Typic Haplaquepts & R-F-F & 15 & 60 & 25 & 17.0 & 1.9 & 9.2 & 3.7 & 0.28 & 3.6 & 0.8 & 0.1 \\
\hline 24 & Gopalpur & Aquic Eutrochrepts & R-F-R & 5 & 88 & 7 & 7.6 & 0.9 & 8.6 & 5.7 & - & 3.4 & 1.2 & 0.6 \\
\hline 25 & Silmondi-2 & Aeric Haplaquepts & R/F-F-R & 6 & 61 & 33 & 12.4 & 1.3 & 9.3 & 4.7 & 0.24 & 4.8 & 0.9 & 0.2 \\
\hline 26 & Sonatala-3 & Aeric Haplaquepts & R-F-R & 18 & 60 & 22 & 12.1 & 1.3 & 9.5 & 4.1 & 0.15 & 3.7 & 0.6 & 0.2 \\
\hline 27 & Gangachhara & Typic Haplaquepts & F-F-R & 27 & 60 & 13 & 10.0 & 1.0 & 10.4 & 4.1 & 0.12 & 2.0 & 1.3 & 0.1 \\
\hline 28 & Ranisankail & Udic Ustochrepts & $\mathrm{P}-\mathrm{F} / \mathrm{J}-\mathrm{R}$ & 71 & 19 & 10 & 6.5 & 0.7 & 9.4 & 4.2 & 0.07 & 0.4 & 0.6 & 0.1 \\
\hline 29 & Amnura & Aeric Albaquepts & P/M-F-R & 19 & 65 & 16 & 12.4 & 1.5 & 8.2 & 4.4 & 0.05 & 1.4 & 0.4 & 0.1 \\
\hline 31 & Pritimpasa & Typic Haplaquepts & F-F-R & 17 & 48 & 35 & 13.2 & 1.4 & 9.6 & 3.9 & 0.19 & 4.3 & 0.7 & 0.2 \\
\hline 32 & Sulla & Typic Haplaquepts & R-F-F & 10 & 31 & 59 & 17.3 & 2.4 & 7.2 & 3.7 & 0.38 & 8.3 & 1.3 & 0.2 \\
\hline 33 & Silmondi-2 & Aeric Haplaquepts & R-F-R & 28 & 52 & 20 & 10.7 & 1.2 & 8.6 & 4.3 & 0.12 & 3.9 & 0.6 & 0.2 \\
\hline 35 & Noadda-2 & Ultic Ustochrepts & R-F-R & 24 & 50 & 26 & 10.5 & 1.1 & 9.3 & 4.1 & - & 6.1 & 1.0 & 0.2 \\
\hline 36 & Kalma & Aeric Albaquepts & R-F-R & 10 & 60 & 30 & 14.4 & 1.5 & 9.7 & 4.8 & - & 7.2 & 0.8 & 0.2 \\
\hline 37 & Karail & Cumulic Humaquepts & R-F-F & 20 & 48 & 32 & 35.2 & 2.7 & 12.8 & 3.4 & - & 4.7 & 1.0 & 0.2 \\
\hline 38 & Sonatala-4 & Aeric Haplaquepts & V-V-R & 29 & 62 & 9 & 8.1 & 0.8 & 10.7 & 4.5 & - & 3.5 & 0.4 & 0.5 \\
\hline
\end{tabular}

${ }^{*} \mathrm{R}$ - rice, $\mathrm{F}$ - fallow, $\mathrm{P}$ - potato, $\mathrm{V}$ - vegetable, $\mathrm{M}$ - mustard, $\mathrm{J}$ - jute.

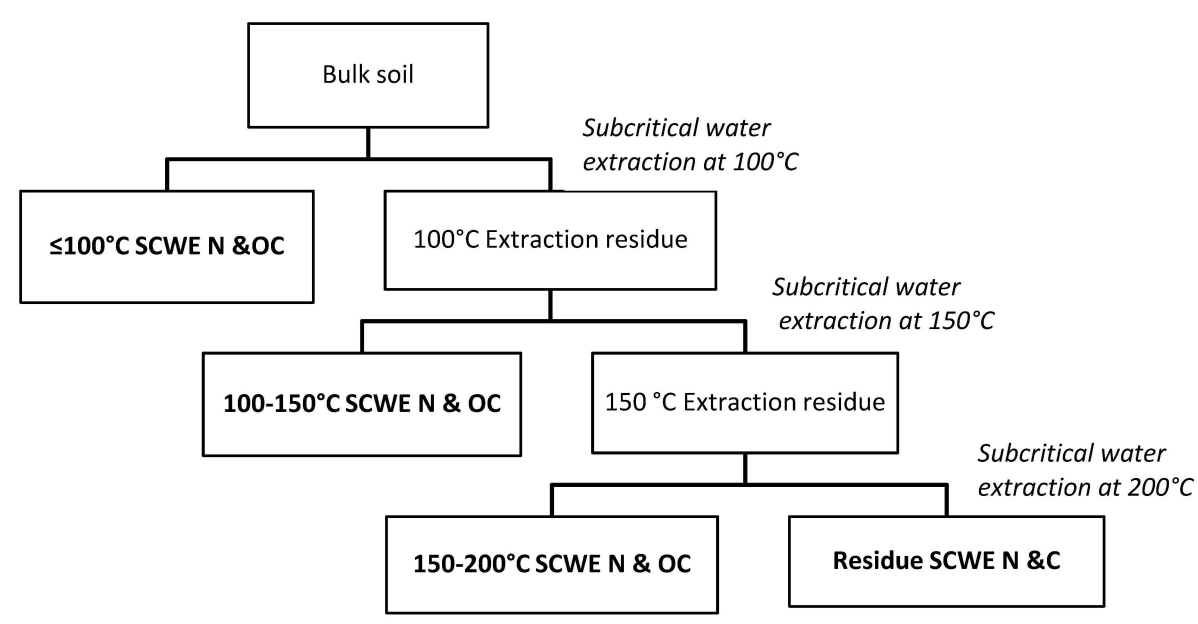

Fig. 1. Schematic of an experimental procedure for the sequential separation of subcritical water extracts. Extractions at 100,150 and $200{ }^{\circ} \mathrm{C}$ were made by means of an accelerated solvent extractor.

\subsection{Statistical analysis}

Pearson's correlation coefficients were calculated to investigate the relation between $\mathrm{N}$ or $\mathrm{C}$ in the isolated SCWE fractions and the aerobic or anaerobic $\mathrm{N}$ mineralization rate. ANOVA (analysis of variance) was used to test for differences in $\mathrm{N}$ or $\mathrm{C}$ or the $\mathrm{C}: \mathrm{N}$ ratio between groups of soils with different mineralogy. Non-linear regression with the Levenberg-Marquardt algorithm was used to estimate the first-order mineralization model parameters. For soils 4 and 24 the parameter $N_{\mathrm{A}}$ had to be constrained to a value below the soil $\mathrm{N}$ content and instead the sequential quadratic programming method was used. Multivariate linear regression was conducted with the $\mathrm{N}$ mineralization rates as dependents 
and the contents of $\mathrm{OC}$ and $\mathrm{N}$ of all the isolated fractions along with general soil properties as independents using SPSS's "stepwise linear regression" function. The successive selection of independents in the final regression model herein takes the form of a sequence of $F$ tests in which the independent variables are successively entered (if $F<P_{\text {in }}=0.05$ ) or removed (if $F>P_{\text {out }}=0.10$ ). All statistical analyses were conducted with IBM SPSS statistics 21.0 (SPSS Inc., USA).

\section{Results}

\subsection{Mineralogical composition}

X-ray diffraction analysis revealed that all studied $\mathrm{K}$ and $\mathrm{Mg}$-saturated clay fractions were composed of a variable admixture of $2: 1$ phyllosilicates (peaks at 1.00, 0.500, and $0.333 \mathrm{~nm})$, kaolinite $(0.713$ and $0.357 \mathrm{~nm})$, quartz $(0.425$ and $0.333 \mathrm{~nm})$, feldspar $(0.320 \mathrm{~nm})$, goethite $(0.418 \mathrm{~nm})$ and lepidocrocite $(0.627 \mathrm{~nm})$. The broad bulge around $1.80 \mathrm{~nm}$ in the $\mathrm{Mg}$-saturated and glycerol-solvated swelled specimens confirmed the presence of smectite in soils 4, 24 and 31. Mica was identified in all 25 soils by the presence of the $1.00 \mathrm{~nm}$ reflection appearing in all the treatments. Vermiculite was identified in 18 soils (not in soils 3, 8, 10, 15, 29, 31 and 37) by a decrease in the peak intensity of the $1.42 \mathrm{~nm}$ reflection and a corresponding increase in the peak intensity of the $1.00 \mathrm{~nm}$ reflection when shifting from $\mathrm{Mg}$ saturation to $\mathrm{K}$ saturation followed by air drying. Chlorite was detected in all soils except in soils 29,35 and 37 by reflections at $1.42 \mathrm{~nm}$ in the $\mathrm{K}$ - and $\mathrm{Mg}$-saturated air dried specimens and its rational orders and by the remains of the $1.42 \mathrm{~nm}$ reflection in the $550{ }^{\circ} \mathrm{C}$-heated $\mathrm{K}$-saturated specimen. Presence of kaolinite was confirmed in all studied soils from peaks or shoulders at 0.716 and $0.357 \mathrm{~nm}$ in the $\mathrm{Mg}$-saturated specimens. In 14 soils, presence of a vermiculite-chlorite intergrade was ascertained by a decrease in peak intensity of the $1.42 \mathrm{~nm}$ reflection after heating the K-saturated specimen. Mostly, very small peaks at $1.25 \mathrm{~nm}$ in all the treatments also suggested the presence of the interstratified mica-chlorite mineral in 11 soils. Quartz and feldspars were identified in all soils, except for feldspars in soils 35, 37 and 38. Goethite and lepidocrocite were identified only in soils 1, 4, 12 and 36 and 10, 16 and 25 , respectively. The X-ray diffraction clay mineralogy is summarized in Table 2.

\subsection{N mineralization}

The evolution of mineral $\mathrm{N}$ during 120 day incubations under aerobic and anaerobic conditions were described in detail by Kader et al. (2013). In summary, over the set of 25 soils the calculated aerobic $\mathrm{N}$ mineralization varied from 10 to $223 \mathrm{mg} \mathrm{N} \mathrm{kg}^{-1} 120$ days $^{-1}$, that is 2.5 to $15 \%$ of the soil $\mathrm{N}$ was mineralized in 120 days, respectively). The anaerobic $\mathrm{N}$ mineralization varied from 34 to $423 \mathrm{mg} \mathrm{N} \mathrm{kg}^{-1} 120$ days $^{-1}$ (4.5 to $28.1 \%$ of soil $\mathrm{N}$, respectively). Over all 25 soils, the mean anaerobic $\mathrm{N}$ mineralization rate was significantly higher (pairwise $t$ test at $P<0.05$ ) than the mean aerobic $\mathrm{N}$ mineralization rate.

\subsection{SCWE fractions}

Four different SOM fractions were obtained from sequential SCWE, namely $\leq 100,100-150$ and $150-200^{\circ} \mathrm{C}$ water extractable and $>200^{\circ} \mathrm{C}$ residual non-extractable $\mathrm{N}$ and $\mathrm{C}$. The sizes of the $\mathrm{N}$ fractions were expressed on a bulk soil basis $\left(\mathrm{g} \mathrm{N} \mathrm{kg}^{-1}\right)$ and are given in Fig. 2. The recovery of $\mathrm{N}$ and $\mathrm{OC}$ was $90.6 \pm 13.4$ and $97.9 \pm 7.2 \%$ of soil $\mathrm{N}$ and soil OC, respectively. The lower recovery of $\mathrm{N}$ compared to OC might have been due to $\mathrm{N}$ volatilization during extraction at higher temperatures. At $100^{\circ} \mathrm{C} \mathrm{SCWE}$ removed 0.01$0.10 \mathrm{~g} \mathrm{~N} \mathrm{~kg}^{-1}, \mathrm{~N}$ representing $1.1-7.7 \%$ of soil $\mathrm{N}$ (Fig. 2), in line with previously reported proportions of hot water extractable $\mathrm{N}$ according to Kader et al. (2010) (2-5\% of soil $\mathrm{N})$, Curtin et al. (2006) (2-7.5\% of soil N) and Leinweber et al. (1995) (3-5\% of soil N). The amount of additional $\mathrm{N}$ extracted at $150^{\circ} \mathrm{C}$ (additional since $100^{\circ} \mathrm{C}$ extractable $\mathrm{OM}$ was already removed by the preceding extraction at $100^{\circ} \mathrm{C}$ ) ranged between 0.06 and $0.29 \mathrm{~g} \mathrm{~N} \mathrm{~kg}^{-1}$, accounting for $7.5-25.2 \%$ of soil N. Another larger share of $24-57 \%$ of soil $\mathrm{N}$ was subsequently extracted at $200^{\circ} \mathrm{C}$ (i.e. 0.18 $1.34 \mathrm{~g} \mathrm{~N} \mathrm{~kg}^{-1}$ ) (Fig. 2). The average $\mathrm{C}: \mathrm{N}$ ratios of these three fractions decreased with increasing extraction temperature from $9.7\left(\leq 100^{\circ} \mathrm{C}\right.$ SCWE fraction) over 8.4 (100$150^{\circ} \mathrm{C} \mathrm{SCWE}$ fraction) to $6.4\left(150-200^{\circ} \mathrm{C} \mathrm{SCWE}\right.$ fraction) (Fig. 3). Over all fractions, the $\leq 100^{\circ} \mathrm{C}$ SCWE fraction's $\mathrm{C}: \mathrm{N}$ ratio showed the largest variation $(5-22)$ and did not significantly differ from the bulk soil's $\mathrm{C}: \mathrm{N}$ ratio, in contrast to the $100-150$ and $150-200^{\circ} \mathrm{C} \mathrm{SCWE}$ fractions. The SCWE residue $\mathrm{N}$ ranged between 0.09 and $1.41 \mathrm{~g} \mathrm{~N} \mathrm{~kg}^{-1}$ and represented the largest isolated soil $\mathrm{N}(24.2-63.1 \%$ of soil $\mathrm{N})$ fraction (Fig. 2). The $\mathrm{C}: \mathrm{N}$ ratio of the extraction residues were logically higher (on average $15.8 \pm 5.2$ ) than the $\mathrm{C}: \mathrm{N}$ ratios of the extracts and bulk soil (all at $P<0.001$ ).

The temperature dependency of release of SCWE N and OC was quantified by fitting an exponential function: SCWE $\mathrm{N}$ or $\mathrm{OC}=a e^{b T}$ to the cumulative amounts of $\mathrm{N}$ and $\mathrm{OC}$ $\left(\mathrm{g} \mathrm{kg}^{-1}\right)$ at 100,150 and $200^{\circ} \mathrm{C} . T$ is the extraction temperature $\left({ }^{\circ} \mathrm{C}\right), a$ is SCWE $\mathrm{N}$ or $\mathrm{OC}$ at $T=0^{\circ} \mathrm{C}$, and $b$ is a constant expressing temperature dependency $\left({ }^{\circ} \mathrm{C}^{-1}\right)$ of SCWE efficiency. This function fitted well to the SCWE-N and SCWE-OC data (average $R^{2}=0.99$ for $\mathrm{N}$ and OC), indicating an exponential increase of extractability of $\mathrm{N}$ and $\mathrm{OC}$ in response to subcritical water temperature increase from 100 to $200^{\circ} \mathrm{C}$ (Fig. 4).

Among the 25 paddy soils, $b$ varied between 0.018 and $0.032{ }^{\circ} \mathrm{C}^{-1}$ for SCWE N and between 0.016 and $0.028^{\circ} \mathrm{C}^{-1}$ for SCWE OC. These values translate to relative increases in SCWE $\mathrm{N}$ and $\mathrm{OC}$ of $2-4 \%$ and $1-3 \%$ per ${ }^{\circ} \mathrm{C}$ increase in extraction temperature, respectively. The $b$ parameter for $\mathrm{OC}$ correlated negatively to the sand percentage $(P<0.05)$, and 


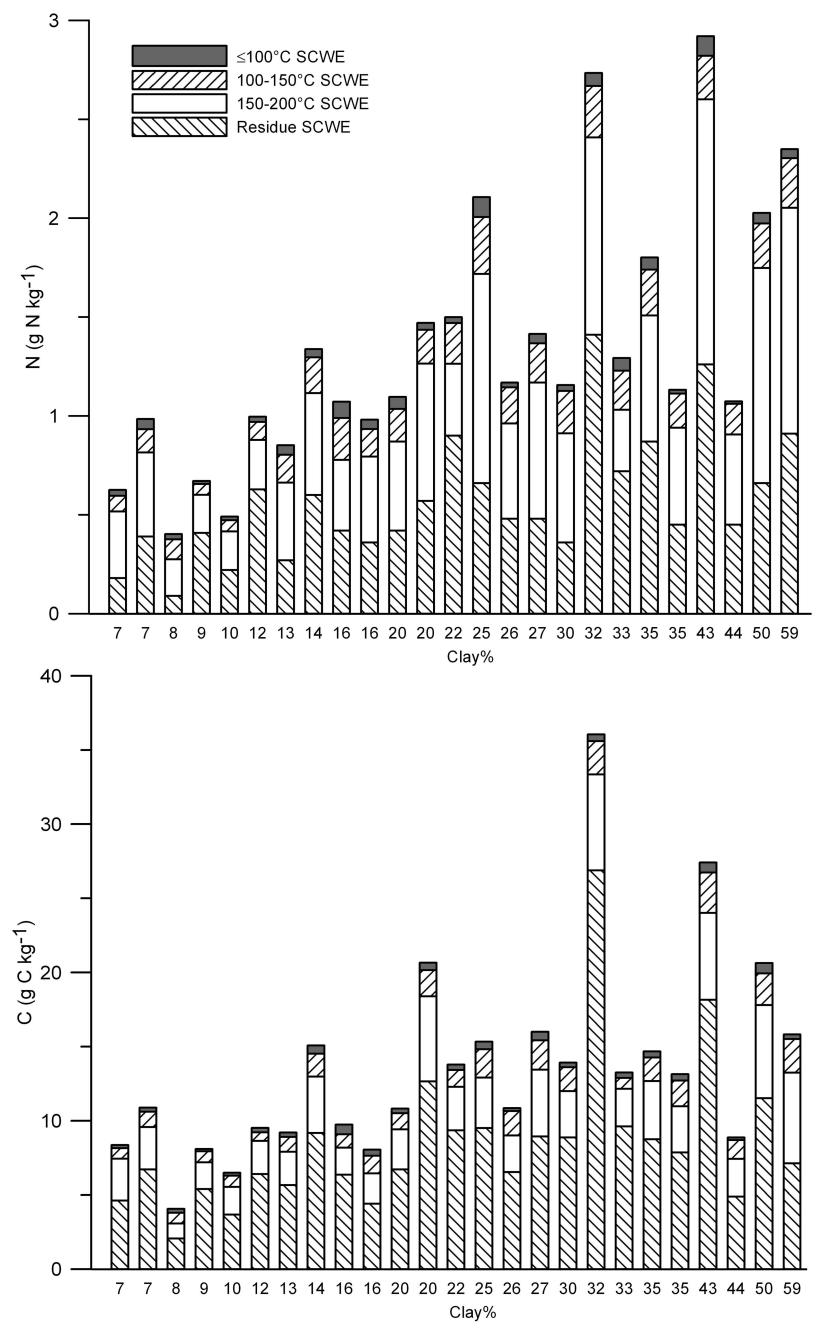

Fig. 2. Distribution of soil $\mathrm{N}$ and $\mathrm{OC}$ over subcritical water fractions. Fractions were subsequently extracted at $100\left(\leq 100^{\circ} \mathrm{C}\right.$ SCWE N or OC), 150 (100- $150^{\circ} \mathrm{C} \mathrm{SCWE} \mathrm{N} \mathrm{or} \mathrm{OC),} 200^{\circ} \mathrm{C}(150-$ $200^{\circ} \mathrm{C} \mathrm{SCWE} \mathrm{N}$ or OC), leaving an extraction residue (Residue SCWE N or OC).

to $\mathrm{Al}_{\mathrm{ox}}(P<0.01)$. The $b$ parameter for $\mathrm{N}$ was only positively correlated to soil $\mathrm{N}$.

\subsection{SCWE $\mathrm{N}$ and $\mathrm{C}$ in relation to soil properties and clay mineralogy}

Pearson's correlation coefficients were firstly calculated between SCWE N and SCWE OC and general soil properties (Table 3). All the isolated SCWE N and SCWE OC fractions correlated significantly and positively with soil N $(P<0.01)$ and soil OC $(P<0.05)$. Correlation coefficients generally increased with increasing extraction temperature. The 100150 and $150-200^{\circ} \mathrm{C} \mathrm{SCWE} \mathrm{N}$ and SCWE OC were strongly correlated with clay percentage, $\mathrm{Fe}_{\mathrm{Ox}}$ and $\mathrm{Al}_{\mathrm{Ox}}$, and fixed $\mathrm{NH}_{4}-\mathrm{N}$ content. On the contrary, $\leq 100^{\circ} \mathrm{C} \mathrm{SCWE} \mathrm{N}$ and OC was not correlated with these soil parameters. SCWE residue

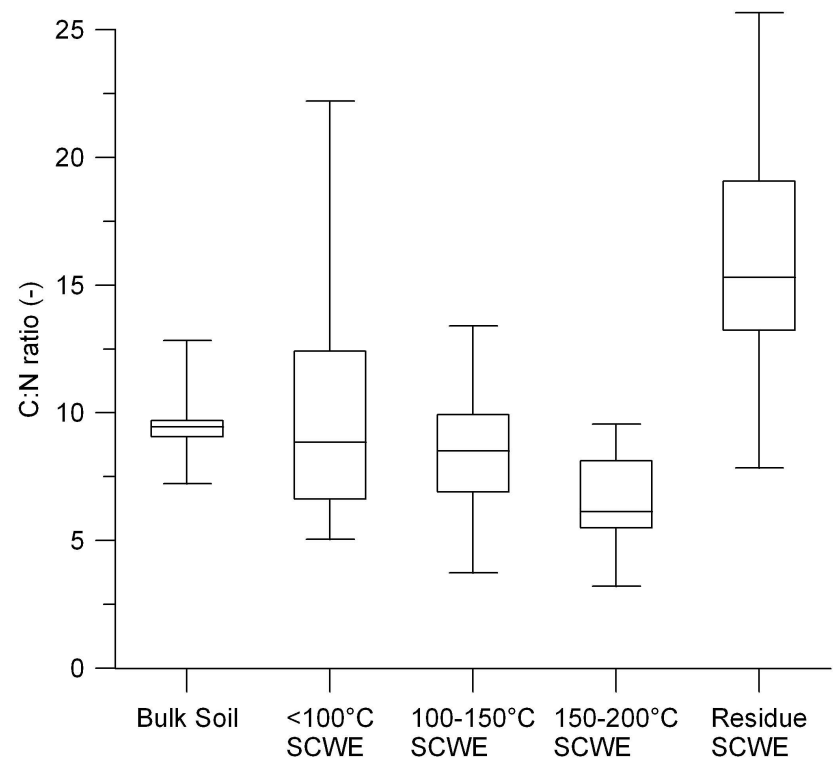

Fig. 3. Average $\mathrm{C}: \mathrm{N}$ ratios of the bulk soil, subcritical water extracts and the extraction residue $(n=25$, error bars show standard deviations).

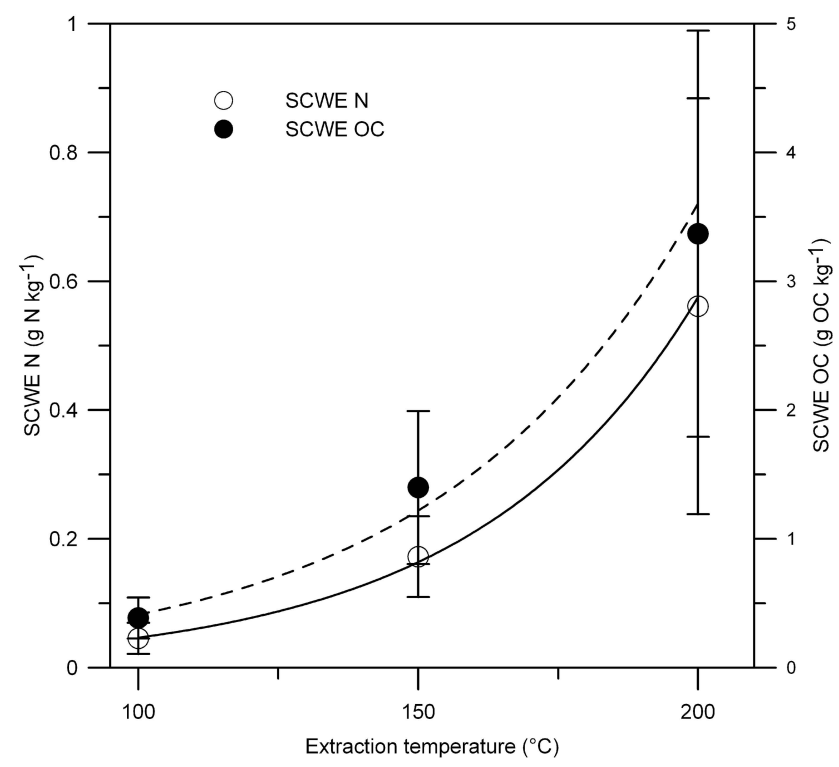

Fig. 4. Release of $\mathrm{N}$ and $\mathrm{OC}$ by subcritical water extraction in function of the extraction temperature. Symbols show means with standard deviations in error bars of 25 paddy soils, line graphs show exponential models fitted to the data.

OC was comparatively weaker $(P<0.05)$ correlated to these general soil properties.

In order to investigate if extractability of $\mathrm{N}$ and $\mathrm{OC}$ by means of SCWE depended on clay mineralogy, relative proportions of clay minerals were estimated by dividing the surface of each identified X-ray diffraction peak by the sum of all peaks in the X-ray diffraction spectra. A correlation 
Table 2. Clay fraction mineralogical composition of sampled agricultural fields in Bangladesh (data from Kader et al., 2013).

\begin{tabular}{|c|c|c|c|c|c|c|c|c|c|c|c|c|}
\hline ID & Soil Series & Mica & Smectite & Vermiculite & Chlorite & Kaolinite & $\mathrm{Vt}-\mathrm{Ch}^{\mathrm{a}}$ & $\mathrm{Mc}-\mathrm{Ch}^{\mathrm{a}}$ & Quartz & Goethite & Lepidocrocite & Feldspar \\
\hline 1 & Sonatala-1 & $\mathrm{xxx}^{\mathrm{b}}$ & & $\mathrm{x}$ & $\mathrm{xxx}$ & $\mathrm{xx}$ & & $\mathrm{x}$ & $\mathrm{x}$ & $\mathrm{x}$ & & $\mathrm{xx}$ \\
\hline 2 & Sonatala-2 & $\mathrm{xxx}$ & & $\mathrm{xx}$ & $\mathrm{xxx}$ & $\mathrm{xx}$ & & $\mathrm{x}$ & $\mathrm{x}$ & & & $\mathrm{x}$ \\
\hline 3 & Faridgonj & $\mathrm{xxx}$ & & & $\mathrm{xxx}$ & $\mathrm{xx}$ & $\mathrm{xx}$ & & $\mathrm{x}$ & & & $\mathrm{xx}$ \\
\hline 8 & Silmondi-1 & $\mathrm{xx}$ & & & $\mathrm{xxx}$ & $\mathrm{xx}$ & $\mathrm{xx}$ & $\mathrm{x}$ & $\mathrm{xx}$ & & & $\mathrm{xx}$ \\
\hline 10 & Ghatail & $\mathrm{xx}$ & & & $\mathrm{xxx}$ & $\mathrm{xx}$ & $\mathrm{xx}$ & & $\mathrm{xx}$ & & $\mathrm{x}$ & $\mathrm{xx}$ \\
\hline 11 & Balina & $\mathrm{xxx}$ & & $\mathrm{x}$ & $\mathrm{xxx}$ & $\mathrm{xx}$ & & & $\mathrm{xx}$ & & & $\mathrm{xx}$ \\
\hline 15 & Gorargao & $\operatorname{xxxx}$ & & & $\mathrm{xx}$ & $\mathrm{xx}$ & $\mathrm{x}$ & $\mathrm{x}$ & $\mathrm{xx}$ & & & $\mathrm{xx}$ \\
\hline 16 & Noadda-1 & $\mathrm{xxx}$ & & $\mathrm{x}$ & $\mathrm{x}$ & $\mathrm{xx}$ & & & $\mathrm{xx}$ & & $\mathrm{x}$ & $\mathrm{x}$ \\
\hline 19 & Dhamrai & $\operatorname{xxxx}$ & & $\mathrm{x}$ & $\mathrm{xxx}$ & $\mathrm{xx}$ & & $\mathrm{x}$ & $\mathrm{xx}$ & & & $\mathrm{xx}$ \\
\hline 24 & Gopalpur & $\mathrm{xxx}$ & $\mathrm{x}$ & $\mathrm{x}$ & $\mathrm{xx}$ & $\mathrm{xx}$ & $\mathrm{x}$ & & $\mathrm{xx}$ & & & $\mathrm{xx}$ \\
\hline 25 & Silmondi-2 & $\mathrm{xxx}$ & & $\mathrm{x}$ & $\mathrm{xxx}$ & $\mathrm{xx}$ & & & $\mathrm{xx}$ & & $\mathrm{x}$ & $\mathrm{xx}$ \\
\hline 26 & Sonatala-3 & $\mathrm{xxx}$ & & $\mathrm{xx}$ & $\mathrm{xxx}$ & $\mathrm{xxx}$ & & & $\mathrm{x}$ & & & $\mathrm{x}$ \\
\hline 32 & Sulla & $\operatorname{xxxx}$ & & $\mathrm{x}$ & $\mathrm{x}$ & $\mathrm{x}$ & $\mathrm{x}$ & & $\mathrm{xx}$ & & & $\mathrm{xx}$ \\
\hline 33 & Silmondi-2 & $\mathrm{xxx}$ & & $\mathrm{x}$ & $\mathrm{xx}$ & $\mathrm{xx}$ & $\mathrm{xx}$ & $\mathrm{x}$ & $\mathrm{x}$ & & & $\mathrm{x}$ \\
\hline 35 & Noadda-2 & $\mathrm{xxx}$ & & $\mathrm{x}$ & & $\mathrm{xx}$ & $\mathrm{x}$ & & $\mathrm{xx}$ & & & \\
\hline 36 & Kalma & $\operatorname{xxxx}$ & & $\mathrm{xx}$ & $\mathrm{xx}$ & $\mathrm{xx}$ & & & $\mathrm{xx}$ & $\mathrm{x}$ & & $\mathrm{x}$ \\
\hline 37 & Karail & $\mathrm{xxx}$ & & & & $\mathrm{xx}$ & $\mathrm{x}$ & & $\mathrm{xx}$ & & & \\
\hline 38 & Sonatala-4 & $\mathrm{xxx}$ & & $\mathrm{x}$ & $\mathrm{XX}$ & $\mathrm{xx}$ & $\mathrm{xx}$ & $\mathrm{xx}$ & $\mathrm{x}$ & & & \\
\hline
\end{tabular}

a Vt-Ch: vermiculite-chlorite interstratified minerals; Mc-Ch: Mica-chlorite interstratified minerals.

b Semi-quantitative analysis of clay fraction mineralogy based on X-ray diffraction patterns: $\mathrm{x}$ - indications of presence; $\mathrm{xx}$ - present; $\mathrm{xxx}$ - substantial presence; $\mathrm{xxxx}$ - abundant.

analysis between the approximate proportions of clay minerals and the relative proportions of SCWE N and OC (\% of soil $\mathrm{N}$ or $\%$ of soil OC) showed that the proportion of $\leq 150^{\circ} \mathrm{C}$ SCWE $\mathrm{N}$ was negatively correlated $(P<0.05)$ to the summed proportion of smectite and vermiculite and vermiculite-chlorite intergrade, while the summed proportion of $100-150$ and $150-200^{\circ} \mathrm{C}$ SCWE N was positively correlated with the proportion of quartz $(P<0.05)$. In addition, the observed decrease in the $\mathrm{C}: \mathrm{N}$ ratio between the 100-150 and the $150-200^{\circ} \mathrm{C} \mathrm{SCWE}$ fractions was correlated to the proportion of kaolinite $(P<0.01)$. Similarly, the difference in the $\mathrm{C}: \mathrm{N}$ ratio between the bulk soil and the 150 $200^{\circ} \mathrm{C}$ SCWE fraction was positively correlated $(P<0.05)$ with the proportion of quartz, but negatively $(P<0.05)$ with the proportion of vermiculite. This decrease in the $\mathrm{C}: \mathrm{N}$ ratio was also significantly higher $(P<0.05)$ for soils containing no vermiculite or smectite (average decrease by 4.1) than for soils containing smectite (average decrease by 1.3).

\subsection{SCWE $\mathrm{N}$ and $\mathrm{OC}$ and $\mathrm{N}$ mineralization}

The $\mathrm{N}$ and OC in all the SCWE fractions and in the bulk soil was significantly correlated with the aerobic $\mathrm{N}$ mineralization rate but not with the anaerobic $\mathrm{N}$ mineralization rate (Table 4). The strongest correlation was found between the aerobic $\mathrm{N}$ mineralization rate and the sum of the $\leq 100$ and $100-150{ }^{\circ} \mathrm{C}$ SCWE $\mathrm{N}$ fractions $(r=0.70)$. A stepwise linear regression was conducted between the aerobic or anaerobic $\mathrm{N}$ mineralization rates and the contents of SCWE N and OC fractions, general soil properties and the $a$ and $b$ parameters of the exponential model describing temperature dependency of cumulative $\mathrm{C}$ and $\mathrm{N}$ extraction by SCWE. Stepwise linear regression withheld only $100+150^{\circ} \mathrm{C}$ SCWE $\mathrm{N}$ as a predictor variable $\left(R^{2}=0.49 ; P<0.01, N=25\right)$ of aerobic $\mathrm{N}$ mineralization. In case of the anaerobic $\mathrm{N}$ mineralization both soil $\mathrm{pH}$ and the $b$ parameter for SCWE OC were withheld $\left(R^{2}=0.54 ; P<0.01, N=25\right)$, with positive coefficients (both at $\mathrm{P} \leq 0.01$ ). The variance inflation factors of the excluded variables, $100-150^{\circ} \mathrm{C}$ SCWE $\mathrm{N}$ and $150+200^{\circ} \mathrm{C}$ SCWE N, were high ( $>3$ ) and all were strongly correlated to the $6 \% \mathrm{NaOCl}$-ox $\mathrm{N}$. This demonstrates multicollinearity and redundancy between these predictor variables and the withheld predictor variable $100+150^{\circ} \mathrm{C}$ SCWE N.

\section{Discussion}

\subsection{SCWE}

The $\leq 100^{\circ} \mathrm{C}$ SCWE $\mathrm{N}$ constituted only but a few percent of total $\mathrm{N}$, while about $40 \%$ of soil $\mathrm{N}$ was extracted at $200^{\circ} \mathrm{C}$. This clearly demonstrates a much higher efficiency of SCWE compared to common "hot-water" extraction. The temperature response of SCWE was well described by an exponential 
Table 3. Pearson's correlation coefficients $(n=25)$ between subcritical water extracted $\mathrm{N}$ and $\mathrm{C}\left(\mathrm{g} \mathrm{kg}^{-1}\right)$, contents of soil N, soil OC, ammonium oxalate extractable $\mathrm{Fe}$ and $\mathrm{Al}\left(\mathrm{Fe}_{\mathrm{ox}}, \mathrm{Al}_{\mathrm{Ox}}\right)$, and fixed $\mathrm{NH}_{4}-\mathrm{N}\left(\mathrm{g} \mathrm{kg}^{-1}\right)$ and the soil clay percentage $(\mathrm{clay} \%)$.

\begin{tabular}{|c|c|c|c|c|c|c|c|c|}
\hline \multirow[b]{2}{*}{ SOM fractions } & \multicolumn{4}{|c|}{ SCWE N } & \multicolumn{4}{|c|}{ SCWE OC } \\
\hline & $\leq 100^{\circ} \mathrm{C}$ & $\begin{array}{l}100- \\
150^{\circ} \mathrm{C}\end{array}$ & $\begin{array}{l}150- \\
200^{\circ} \mathrm{C}\end{array}$ & Residue & $\leq 100^{\circ} \mathrm{C}$ & $\begin{array}{l}100- \\
150^{\circ} \mathrm{C}\end{array}$ & $\begin{array}{l}150- \\
200^{\circ} \mathrm{C}\end{array}$ & Residue \\
\hline Soil N & $0.64^{* * a}$ & $0.77^{* *}$ & $0.92^{* *}$ & $0.85^{* *}$ & $0.69^{* *}$ & $0.88^{* *}$ & $0.91^{* *}$ & $0.83^{* *}$ \\
\hline Soil OC & $0.56^{* *}$ & $0.69^{* *}$ & $0.83^{* *}$ & $0.85^{* *}$ & $0.64^{* *}$ & $0.83^{* *}$ & $0.88^{* *}$ & $0.96^{* *}$ \\
\hline Clay \% & 0.24 & $0.70^{* *}$ & $0.73^{* *}$ & $0.59^{* *}$ & 0.33 & $0.74^{* *}$ & $0.68^{* *}$ & $0.41^{*}$ \\
\hline $\mathrm{Fe}_{\mathrm{ox}}$ & -0.03 & $0.56^{* *}$ & $0.46^{*}$ & $0.43^{*}$ & 0.00 & $0.54^{* *}$ & $0.51^{* *}$ & 0.26 \\
\hline $\mathrm{Al}_{\mathrm{Ox}}$ & 0.22 & $0.42^{*}$ & $0.63^{* *}$ & $0.43^{*}$ & 0.15 & $0.57^{* *}$ & $0.64^{* *}$ & $0.41^{*}$ \\
\hline Fixed $\mathrm{NH}_{4}-\mathrm{N}^{\mathrm{b}}$ & 0.33 & $0.72^{* *}$ & $0.77^{* *}$ & $0.74^{* *}$ & 0.28 & $0.72^{* *}$ & $0.78^{* *}$ & $0.57^{*}$ \\
\hline
\end{tabular}

a * Correlation is significant at $P<0.05$ (2-tailed); ${ }^{* *}$ Correlation is significant at $P<0.01$ (2-tailed).

$\mathrm{b}(n=18)$

Table 4. Pearson's correlation coefficients between amounts $\left(\mathrm{g} \mathrm{kg}^{-1}\right)$ of SCWE $\mathrm{N}$ and OC and the rate of soil $\mathrm{N}$ mineralization, measured under aerobic and anaerobic conditions.

\begin{tabular}{|c|c|c|}
\hline \multirow[b]{2}{*}{ Soil fraction } & \multicolumn{2}{|c|}{$\begin{array}{l}\mathrm{N} \text { mineralization rate } \\
\left(\mathrm{mg} \mathrm{N} \mathrm{kg}^{-1} \text { day }^{-1}\right)\end{array}$} \\
\hline & Aerobic & Anaerobic \\
\hline Soil N & $0.64^{* *}$ & 0.24 \\
\hline Soil OC & $0.60^{* *}$ & 0.33 \\
\hline$\leq 100^{\circ} \mathrm{C} \mathrm{SCWE} \mathrm{N}$ & $0.57^{* *}$ & 0.10 \\
\hline$\overline{1} 00-150^{\circ} \mathrm{C}$ SCWE N & $0.68^{* *}$ & 0.35 \\
\hline $150-200^{\circ} \mathrm{C} \mathrm{SCWE} \mathrm{N}$ & $0.58^{* *}$ & 0.30 \\
\hline SCWE Residue N & $0.44^{*}$ & 0.33 \\
\hline $100+150^{\circ} \mathrm{C} \mathrm{SCWE} \mathrm{N}$ & $0.70^{* *}$ & 0.30 \\
\hline $150+200^{\circ} \mathrm{C} \mathrm{SCWE} \mathrm{N}$ & $0.61^{* *}$ & 0.32 \\
\hline$\leq 100^{\circ} \mathrm{C} \mathrm{SCWE} \mathrm{OC}$ & $0.44^{*}$ & -0.23 \\
\hline $100-150^{\circ} \mathrm{C}$ SCWE OC & $0.48^{*}$ & 0.32 \\
\hline $150-200^{\circ} \mathrm{C}$ SCWE OC & $0.49^{*}$ & 0.21 \\
\hline SCWE Residue OC & $0.50^{*}$ & -0.04 \\
\hline $100+150^{\circ} \mathrm{C} \mathrm{SCWE} \mathrm{OC}$ & $0.51^{* *}$ & 0.22 \\
\hline $150+200^{\circ} \mathrm{C} \mathrm{SCWE} \mathrm{OC}$ & $0.50^{*}$ & 0.25 \\
\hline
\end{tabular}

model (Fig. 4), consistent with Martinez et al. (2003), who found a nearly doubling of water extractable $\mathrm{N}$ and $\mathrm{OC}$ when the extraction temperature was raised from 10 to $50^{\circ} \mathrm{C}$ and a nearly triple increase between 50 and $90^{\circ} \mathrm{C}$. The observed relative increases of SCWE $\mathrm{N}$ and $\mathrm{OC}$ per ${ }^{\circ} \mathrm{C}$ extraction temperature were also in line with findings of Chantigny et al. (2010), who reported a relative increase in water extractable $\mathrm{OC}$ of $1.4-5.3 \%$ per ${ }^{\circ} \mathrm{C}$ increase within a gradient from 20 to $80^{\circ} \mathrm{C}$. Organic macromolecules may change from a rigid "glassy" state to a more flexible "rubbery" condition as temperature increases (Zhang et al., 2007) along with a decreasing viscosity of humic substances (Boutaric and Thenevet, 1937) and it is possible that this increases the water solubility of humic materials. However, changing physical properties of the solvent itself, in this case water, with temperature could have also determined extraction of soil $\mathrm{N}$ by SCWE. Water is a very polar solvent with a dielectric constant of 78.4 at $25^{\circ} \mathrm{C}$ and $0.1 \mathrm{MPa}$ and this limits the potential to extract important non-polar organic $\mathrm{N}$ components like non-polar amino acids (e.g. valine, alanine, leucine, methionine, and proline) and many proteins. However, as water's temperature and pressure increase, the thermal energy excess disorients individual molecular dipoles and lessens the strong dipole-dipole electrostatic interactions within the liquid, which results in lower dielectric constants (Fernandez et al., 1997). For example, the dielectric constant of water decreases to 31.5 at $225^{\circ} \mathrm{C}$ and $20 \mathrm{MPa}$, which is very close to the dielectric constant of a less polar organic solvent like methanol (32.6 at $25^{\circ} \mathrm{C}$ and $0.1 \mathrm{MPa}$ ) (Wohlfarth, 1991). Under these circumstances most lipids and heterocycles should still be insoluble. The gradual lowering in $\mathrm{C}: \mathrm{N}$ ratio from 9.7 for the $\leq 100^{\circ} \mathrm{C}$ over 8.4 at $100-150{ }^{\circ} \mathrm{C}$ to 6.4 at 150 $200^{\circ} \mathrm{C}$ fractions indeed revealed an increasing selectivity to $\mathrm{N}$ over OC (in more hydrophobic substances) with increasing SCWE temperature. Gregorich et al. (2003) observed that the $\mathrm{C}: \mathrm{N}$ ratio of water-extracted SOM was decreased with increasing extraction temperature from room temperature to $80^{\circ} \mathrm{C}$. They suggested that hot water facilitates the release of hydrophilic organic N. Schnitzer et al. (1991) also found a more efficient extraction of organic $\mathrm{N}$ than of other $\mathrm{OM}$ components at $200^{\circ} \mathrm{C}$. They attributed the greater affinity of subcritical water at $200^{\circ} \mathrm{C}$ to the greater polarity of many $\mathrm{N}$ containing compounds, compared with carbohydrates and lignin- and phenol-derived aromatics. In view of these observations, it appears that by "tuning" of the dielectric constant through choice of SCWE temperature one can isolate OM fractions with differing solubility of $\mathrm{N}$ and $\mathrm{OC}$ in water.

Next to the temperature dependency of solubility of SOM in water, variation in strength of OM-mineral interactions most probably governs the extractability of soil $\mathrm{N}$ and $\mathrm{C}$ at different temperatures. In line with this, we expected clay 
content and mineralogy to determine SCWE efficiency and its dependency on temperature. Firstly, the significant positive correlations between the SCWE temperature dependency model parameter $b$ for OC and clay percentage and $\mathrm{Al}_{\mathrm{Ox}}$ and $\mathrm{Mn}_{\mathrm{Ox}}$ confirm this for OC. In other words, higher extraction temperatures are required to extract equal amounts of OM from soils with higher content of clay or pedogenic oxides. Additionally, the data suggest that extraction of mineral bound $\mathrm{N}$ and $\mathrm{OC}$ primarily occurred at extraction temperatures above $100^{\circ} \mathrm{C}$ as only the $100-150$ and $150-200^{\circ} \mathrm{C}$, but not $\leq 100^{\circ} \mathrm{C} \mathrm{SCWE} \mathrm{N}$ and $\mathrm{OC}$, correlated positively with the soil clay percentage and contents of $\mathrm{Fe}_{\mathrm{ox}}$ and $\mathrm{Al}_{\mathrm{Ox}}$. Similarly, fixed $\mathrm{NH}_{4}-\mathrm{N}$ did not correlate to $\leq 100^{\circ} \mathrm{C} \mathrm{SCWE}$ $\mathrm{N}$, indicating that fixed $\mathrm{NH}_{4}-\mathrm{N}$ was extracted primarily by SCWE above $100^{\circ} \mathrm{C}$. Secondly, the proportions of smectite and vermiculite correlated negatively with SCWE N, while the proportion of quartz was positively correlated. There was furthermore a negative correlation between $b$ for $\mathrm{N}$ and the summed proportion of 2:1 clay minerals (though only at $P=0.075)$. From this we conclude a lower efficiency of SCWE in soils with increasingly reactive clay mineralogy. In addition, the increasing selectivity of SCWE towards $\mathrm{N}$ over $\mathrm{C}$ at higher temperatures, as indicated by the shift in $\mathrm{C}: \mathrm{N}$ ratio in the SCWE fractions, depended on clay mineralogy as well. SCWE was more selective towards $\mathrm{N}$ with decreasing proportion of high surface area clay minerals like smectite and vermiculite.

To interpret these data, an analogy could be made to data obtained by pyrolysis field ionization mass spectroscopy, in which the temperature dependent release of individual OM molecular markers is resolved. Schulten and Leinweber (1999) found that volatilization of mineral bound OM requires higher temperatures than unbound $\mathrm{OM}$ to enable thermal bond cleavage. They identified three thermal classes: (i) unbound undecomposed plant fragments relatively rich in aliphatics; (ii) a thermally labile fraction containing Ncontaining compounds and carbohydrates associated with humified OM and (iii) thermally stable mineral bound OM. On the basis of the data in this study it seems plausible to hypothesize that SCWE at $100^{\circ} \mathrm{C}$ primarily releases weak or intermediately bound $\mathrm{N}$ and $\mathrm{OC}$, i.e. belonging to the second SOM pool identified by Schulten and Leinweber (1999). The first pool may well be of lesser importance because unbound undecomposed OM in fact comprises but a relatively small share of the soil $\mathrm{N}$ and is probably poorly extractable due to its particulate nature. Leinweber et al. (1995) found hot water extractable $\mathrm{OM}$ to be largely composed of carbohydrates and $\mathrm{N}$ containing compounds and since many of these constituents volatilized at lower temperatures during pyrolysis, it was concluded that they were in soil solution or just weakly sorbed to mineral surfaces or humic macromolecules. It seems acceptable that such material formed a major part of the SCWE fractions. At 150 and $200^{\circ} \mathrm{C}$, SCWE probably extracted increasingly more $\mathrm{OM}$, which is strongly bound to minerals, i.e. belonging to the third pool defined by Schul- ten and Leinweber (1999). This was indirectly confirmed by correlation analysis with the clay percentage and contents of $\mathrm{Fe}_{\mathrm{ox}}$ and $\mathrm{Al}_{\mathrm{ox}}$, as described above. Yet, direct supporting evidence should come from SCWE extraction of well known model OM-mineral mixtures. In addition, the average $\mathrm{C}: \mathrm{N}$ ratio of the $150-200^{\circ} \mathrm{C} \mathrm{SCWE}$ fraction was 6.4 , i.e. close to commonly observed clay fraction $\mathrm{C}: \mathrm{N}$ ratios. This again suggests that $\mathrm{OM}$ bound to clay minerals or to pedogenic oxides was extracted by SCWE at $200^{\circ} \mathrm{C}$. As selectivity of SCWE towards $\mathrm{N}$ over $\mathrm{C}$ increased with decreasing proportions of smectite and vermiculite, it appears that extraction of $\mathrm{N}$ bound to such highly reactive minerals may have been limited.

\subsection{SCWE $\mathrm{N}$ and $\mathrm{C}$ and $\mathrm{N}$ mineralization}

The range in soil $\mathrm{N}\left(0.4-3.2 \mathrm{~g} \mathrm{~kg}^{-1}\right)$, clay content (7.4$58.7 \%$ ), crop rotation (single or double annual rice crops) and mineralogy (Table 1) allowed a robust and meaningful evaluation of the SCWE $\mathrm{N}$ fractions as indices for $\mathrm{N}$ mineralization in paddy soils. This variation in the sampled soil set was also accompanied by a wide variation in the aerobic and anaerobic $\mathrm{N}$ mineralization rates.

The mean correlation coefficient $r$ between soil $\mathrm{N}$ content and the aerobic $\mathrm{N}$ mineralization rate was 0.64 (Table 4), indicating that soil $\mathrm{N}$ content generally explained only $41 \%$ of the observed variation in the $\mathrm{N}$ mineralization rate. Several researchers found the quality of soil $\mathrm{N}$, as quantified by a distribution of $\mathrm{N}$ over physicochemical fractions or by the biochemical composition of SOM, to have a greater influence on mineralization of $\mathrm{N}$ than soil $\mathrm{N}$ or soil OC content (Yonebayashi and Hattori 1986; Olk et al., 1996, Cassman et al., 1996). For the 25 studied soils, however, only slightly stronger correlations were found with the $100-150^{\circ} \mathrm{C}$ SCWE $\mathrm{N}(r=0.68)$ and with the sum of the $\leq 100$ and $100-150^{\circ} \mathrm{C}$ SCWE N $(r=0.70)$ (Table 4$)$. The resulting percentages of explained variance (46-49\%) are still too small to allow accurate fertilizer recommendations according to the guidelines given by Malley et al. (2004), who suggested that $R^{2}$ values of calibrated soil tests should be more than $83 \%$ (Ros, 2012). Surprisingly, $\leq 100^{\circ} \mathrm{C}$ SCWE $N$ had a weaker correlation with the aerobic and anaerobic $\mathrm{N}$ mineralization rates than soil N, although hot water extractable $\mathrm{N}$ (mostly at 80 $100^{\circ} \mathrm{C}$ ) has been widely used as an index of plant available N (Broner and Bachler, 1980; Ghani et al., 2003; Curtin et al., 2006) and is considered to be composed of bio-available $\mathrm{N}$-containing compounds (Landgraf et al., 2006). Unexpectedly, the sequential SCWE residue $\mathrm{N}$ correlated positively to the aerobic $\mathrm{N}$ mineralization rate. This relationship may have been indirect, though, because SCWE residue $\mathrm{N}$ was also strongly correlated to soil $\mathrm{N}$ content (Table 3 ) and constituted the largest isolated soil $\mathrm{N}$ fraction.

Finally, we assessed combinations of the isolated $\mathrm{N}$ and OC fractions and general soil properties as predictors of the $\mathrm{N}$ mineralization rate through multivariate regression, but 
explained variances remained low with a maximal $R^{2}$ of 0.54 for anaerobic $\mathrm{N}$ mineralization. We found no significant correlations at all between $\mathrm{N}$ or OC in any of the isolated soil fractions and the anaerobic $\mathrm{N}$ mineralization rate. Instead, soil $\mathrm{pH}$ and the SCWE OC temperature dependency model $b$ parameter were the best predictors of anaerobic $\mathrm{N}$ mineralization, with negative and positive linear regression coefficients, respectively. The latter suggests, surprisingly, that $\mathrm{N}$ mineralization was higher in soils for which higher temperatures are required to extract soil $\mathrm{OC}$, i.e. with a higher value of $b$. It would appear, however, that this relation was in fact indirect as at the same time $b$ for OC correlated positively to $\mathrm{Al}_{\mathrm{Ox}}$ and $\mathrm{Mn}_{\mathrm{Ox}}$ and negatively to the sand percentage. In line, soil $\mathrm{pH}$ correlated positively to the silt percentage and negatively to the quartz percentage and $\mathrm{Mn}_{\mathrm{Ox}}$. Both predictors ( $\mathrm{pH}$ and $b$ ) therefore appear to depend on soil texture and content of pedogenic oxides. This designates that SOM quality, at least when expressed as a distribution of $\mathrm{N}$ and $\mathrm{C}$ over isolated SCWE fractions, does not control the anaerobic $\mathrm{N}$ mineralization process at all and instead abiotic factors are of importance. In a previous study by Kader (2012) it was found that the $\mathrm{N}$ mineralization of these soils collected from agricultural fields was also not explained by content of $\mathrm{N}$ in different physicochemical fractions, including sand $\mathrm{N}$, silt + clay N, $6 \% \mathrm{NaOCl}$ oxidizable $\mathrm{N}$ and $10 \% \mathrm{HF}-$ extractable N. Instead Kader et al. (2013) suggested that abiotic factors like availability of reducible $\mathrm{Fe}$, mineralogy and $\mathrm{pH}$ could play a decisive role, but this needs to be confirmed through further research. In line, Sahrawat and Narteh (2003) found reducible $\mathrm{Fe}$ to be a useful indicator to predict ammonium production in 15 west African rice soils. Most of the sampled Bangladeshi paddy soils are in a fairly early stage of soil development with relatively low content of pedogenic oxides and active clay mineralogy. Both aspects could be of importance to mineral $\mathrm{N}$ release under anoxic conditions in the studied soils. Firstly, as redox potential progressively lowers after onset of submergence electron acceptors alternative to rapidly depleted $\mathrm{O}_{2}$ and $\mathrm{NO}_{3}$, viz. $\mathrm{Mn}^{4+}$ and $\mathrm{Fe}^{3+}$, are required for $\mathrm{OM}$ decomposition to proceed. The availability of both would be limited in soils having a low pedogenic oxide content, and this may form a bottleneck for anaerobic $\mathrm{N}$ mineralization. Secondly, vermiculite containing paddy soils accumulate fixed $\mathrm{NH}_{4}^{+}$(estimated to 100$800 \mathrm{~kg} \mathrm{~N} \mathrm{ha}^{-1} 15 \mathrm{~cm}^{-1}$ in the studied soils). It has, however, often been shown that a part of the fixed $\mathrm{NH}_{4}-\mathrm{N}$ is in fact dynamic (Nieder et al., 2011) and therefore release of fixed $\mathrm{NH}_{4}^{+}$may well have contributed to build-up of exchangeable $\mathrm{NH}_{4}^{+}$during the anaerobic lab incubations. It has also been shown that microbial reduction of $\mathrm{Fe}^{3+}$ followed by dissolution of Fe-oxides coated on the surfaces of clay minerals is a prerequisite for fixed $\mathrm{NH}_{4}^{+}$exchange (Scherer and Zhang, 1999). Following these two points, again abiotic factors like clay mineralogy and content of pedogenic oxides, rather than SOM quality, should be of importance to the net- release of exchangeable $\mathrm{NH}_{4}^{+}$under anaerobic conditions in young paddy soils, in line with our regression analysis. In conclusion, quality and quantity of $\mathrm{N}$ fractions only partly explained the aerobic $\mathrm{N}$ mineralization and not anaerobic $\mathrm{N}$ mineralization of the studied set of 25 paddy soils and consequently alternative driving factors than the soil fractions isolated here should be looked for. The biochemistry of paddy soils is, however, controlled by complex interactions between redox potential, $\mathrm{pH}$, solubility of OM (KögelKnabner et al., 2010) and availability of electron acceptors (Sahrawat, 2004).

Maybe we should not discard SCWE as a means for isolation of $\mathrm{N}$ pools with differing proneness to microbial decay, solely on the basis of this particular study on paddy soils. Bio-availability of $\mathrm{N}$, approximated here by extractability of $\mathrm{N}$ at different temperatures, may well play a more important role in well-drained upland agricultural soils. Perhaps SCWE holds potential to separate kinetically different SOM pools in these soils. Indeed, the aerobic $\mathrm{N}$ mineralization did relate to several $>100^{\circ} \mathrm{C}$ SCWE $\mathrm{N}$ fractions, although still with but a limited higher predictive power than soil $\mathrm{N}$ content. Under aerobic conditions, microbial activity is no longer dependant on availability of alternative electron acceptors and instead, as revealed by several authors (Appelqvist et al., 1996; Schulten and Schnitzer, 1997; Leinweber and Schulten, 2000; Kleber et al., 2007), association of organic $\mathrm{N}$ with soil mineral components is the dominant mechanism explaining the persistence of these inherently biologically labile SOM constituents. Our study, in line with Schnitzer et al. (1991), demonstrated that $\mathrm{N}$ is preferentially extracted over $\mathrm{C}$ with increasing temperature by SCWE and that the extraction efficiency depended on soil mineralogy. This suggests that SCWE at different temperature intervals may be able to isolate specific OM- or mineral-associated $\mathrm{N}$ fractions, which are likely to be differently bio-available. In light of mineral association of $\mathrm{N}$, an important difference between young floodplain paddy soils and more developed upland soils may be their contents of pedogenic oxides, as these have been identified as specific important binding sites for organic $\mathrm{N}$ in sand to loam textured croplands in Germany (Leinweber and Schulten, 2000). Since the content of pedogenic oxides was low in the studied set of paddy soils we were not able to test the potential of SCWE to extract differently bound $\mathrm{N}$ pools that would be relevant to upland soils. It would be most interesting to see if and how SCWE is able to separate OM-associated $\mathrm{N}$, pedogenic oxide bound $\mathrm{N}, \mathrm{NH}_{4}^{+}$ in clay mineral interlayers and $\mathrm{N}$ bound to clay minerals.

\section{Conclusions}

This study shows that SCWE can be used to preferentially extract $\mathrm{N}$ from soil and that the quantity of extracted $\mathrm{N}$ increases exponentially with the increase of temperature. The data suggested that extraction of mineral bound $\mathrm{N}$ and $\mathrm{OC}$ 
primarily starts above $100{ }^{\circ} \mathrm{C}$ and increases with temperature as well. Clay mineralogy also seems to significantly affect the extractability of $\mathrm{N}$ and $\mathrm{OC}$ by SCWE. Eventually, at $200^{\circ} \mathrm{C}$ probably mostly clay fraction mineral bound $\mathrm{OM}$ is released by SCWE as seen from the negative relation between the extracts' $\mathrm{C}: \mathrm{N}$ ratio and extraction temperature (to only 6.4 at $200^{\circ} \mathrm{C}$ ). We hypothesize that the stepwise SCWE at 100,150 and $200^{\circ} \mathrm{C}$ SCWE incrementally removed $\mathrm{OM}$ that is more strongly mineral bound and less OM that is weakly associated to mineral matter or SOM. If so, the three isolated SCWE fractions would each form mixtures of SOM pools with differing thermostability and perhaps also biodegradability. However, it seems that the sequential SCWE procedure was in fact unable to completely isolate kinetically labile from stable (mineral bound and/or biochemically recalcitrant) organic $\mathrm{N}$, as the amount of $\mathrm{N}$ in each of the SCWE fractions and in the SCWE residue correlated with the aerobic $\mathrm{N}$ mineralization rate, indicating the presence of labile $\mathrm{N}$ in all of them. Alternatively, relations between $\mathrm{N}$ mineralization and SCWE extracted $\mathrm{N}$ may have been indirect since mutual positive correlations existed with soil $\mathrm{N}$ content. The present investigation of the SCWE procedure was conducted on a set of paddy soils, in which $\mathrm{N}$ mineralization seemed to be decoupled from SOM quantity or quality. Perhaps SCWE does, however, hold potential to separate kinetically different SOM pools in upland soils where the bio-availability of $\mathrm{N}$ is likely a key constraint in the $\mathrm{N}$ mineralization process.

Acknowledgements. MA Kader wishes to acknowledge the Flemish Inter-University Council (VLIR) for providing him a Ph.D. grant to carry out this research. S. Sleutel is working as a postdoctoral researcher for the Research Foundation Flanders (FWO). This research was partly funded by FWO grant 1.5.088.10N. The FWO is also acknowledged for the funding of the ASE equipment $(1.5 .062 .09 \mathrm{~N})$.

Edited by: S. Bouillon

\section{References}

Appelqvist, I. A. M, Graham, C. L., and Hayes, M. H. B.: Isolation, fractionation, and characterization of humic acids from a sapric histosol, in: Humic Substances and Organic Matter in Soil and Water Environments, edited by: Clapp, C. E., Hayes, M. H. B., Senesi, N., and Griffith, S. M., IHSS, University of Minnesota, St. Paul, 33-39, 1996.

Amashukeli, X., Grunthaner, F. J., Patrick, S. B., and Yung, P. T.: Subcritical water extractor for mars analog soil analysis, Astrobiology, 8, 597-604, 2008.

Augus, J. F., Ohnishi, M., Horie, T., and Williams, R. L.: A preliminary study to predict net nitrogen mineralization in a flooded rice soil using anaerobic incubation, Aust. J. Exp. Agr., 34, 995-999, 1994.
Bangladesh Meteorological Department: available at: http://www. bmd.gov.bd/Document/climateofbangladesh.doc (last access: 14 February 2011), 2011.

Boutaric, A. and Thenevet, S.: Recherches physico-chimiques surles colloïdes humiques, Ann. Agron., 7, 18-32, 1937.

Broner, H. and Bachler, W.: Evaluating the nitrogen requirement of sugarbeet from hydrolyzable soil nitrogen, Soil Sci., 130, 303306, 1980.

Buresh, R. J., Reddy, K. R, and van Kessel, C.: Nitrogen transformations in submerged soils, in: Nitrogen in agricultural systems. Agronomy Monograph 49, edited by: Schepers, J. S. and Raun, W. R., ASA, CSSA, and SSSA publishers inc., Madison WI, USA, 401-436, 2008.

Cassman, K. G., Dobermann, A., Sta Cruz, P. C., Gines, G. C., Samson, M. I., Descalsota, M., Alcantara, J. M., Dizon, M. A., and Olk, D. C.: Organic matter and the indigenous nitrogen supply of intensive irrigated systems in the tropics, Plant Soil, 182, 267278, 1996.

Chantigny, M. H., Curtin, D., Beare, M. H., and Greenfield, L. G.: Influence of Temperature on Water-Extractable Organic Matter and Ammonium Production in Mineral Soil, Soil Sci. Soc. Am. J., 74, 517-524, 2010.

Curtin, D. and McCallum, F. M.: Biological and chemical assays to estimate nitrogen supplying power of soils with contrasting management histories, Aust. J. Soil Res., 42, 737-746, 2004.

Curtin, D., Wright, C. E., Beare, M. H., and McCallum, F. M.: Hot water extractable nitrogen as an indicator of soil nitrogen availability, Soil Sci. Soc. Am. J., 70, 1512-1521, 2006.

Fernandez, D. P, Goodwin, A. R. H., Lemmon, E. W., Sengers, J. M. H. L., and Williams, R. C.: A formulation for the static permittivity of water and steam at temperatures from $238 \mathrm{~K}$ to 873 $\mathrm{K}$ at pressures up to $1200 \mathrm{MPa}$, including derivatives and DebyeHückel coefficients, J. Phys. Chem. Ref. Data, 26, 1125-1166, 1997.

Ghani, A., Dexter, M., and Perrott, K. W.: Hot water extractable carbon in soils: a sensitive measurement for determining impacts of fertilisation, grazing and cultivation, Soil Biol. Biochem., 35, 1231-1243, 2003.

Gregorich, E. G., Beare, M. H., Stoklas, U., and St-Georges, P.: Biodegradability of soluble organic matter in maize cropped soils, Geoderma, 113, 237-252, 2003.

Kader, M. A.: Nitrogen mineralization in subtropical paddy soils in relation to soil properties, organic matter fractions, and fertilizer management, PhD Thesis, Faculty of Bioscience Engineering, Ghent University, Ghent, 2012.

Kader, M. A., Sleutel, S., Begum, S. A., D’Haene, K., Jegajeevagan, K., and De Neve, S.: Soil organic matter fractionation as a tool for predicting nitrogen mineralization in silty arable soils, Soil Use Manage., 26, 494-507, 2010.

Kader, M. A., Sleutel, S., Begum, S. A., Moslehuddin, A. Z. M., and De Neve, S.: Nitrogen mineralization in sub-tropical paddy soils in relation to soil mineralogy, management, soil type and C, N and Fe contents, Eur. J. Soil Sci., 64, 47-57, 2013.

Kalbitz, K., Scheswig, D., Rethemeyer, J., and Matzner, E.: Stabilization of dissolved organic matter by sorption to the mineral soil, Soil Biol. Biochem., 37, 1319-1331, 2005.

Kleber, M., Sollins, P., and Sutton, R.: A conceptual model of organo-mineral interactions in soils: self-assembly of organic 
molecular fragments into zonal structures on mineral surfaces, Biogeochemistry, 85, 9-24, 2007.

Knicker, H.: Biogenic nitrogen in soils as revealed by solid-state 13C and 15N NMR spectroscopy, J. Environ. Qual., 29, 715723, 2000.

Kögel-Knabner, I., Guggenberger, G., Kleber, M., Kandeler, E., Kalbitz, K., Scheu, S., Eusterhues, K., and Leinweber, P.: Organo-mineral associations in temperate soils: Integrating biology, mineralogy, and organic matter chemistry, J. Plant Nutr. Soil Sci., 171, 5-13, 2008.

Kögel-Knabner, I., Amelung, W., Cao, Z., Fiedler, S., Frenzel, P., Jahn, R., Kalbitz, K., Kölbl, A., and Schloter, M.: Biogeochemistry of paddy soils, Geoderma, 157, 1-14, 2010.

Koroleff, F.: Simultaneous oxidation of nitrogen and phosphorus compounds by persulphate, in: Methods of seawater analysis, edited by: Grasshoff, K., Eberhardt, M., and Kremling, K., Verlag Chemie, Weinheim, 168-169, 1983.

Lagadec, A. J. M., Miller, D. J., Lilke, A. V., and Hawthorne, S. B.: Pilot-scale subcritical water remediation of polycyclic aromatic hydrocarbon- and pesticide-contaminated soil, Environ. Sci. Technol., 34, 1542-1548, 2000.

Landgraf, D., Leinweber, P., and Makeschin, F.: Cold and hot water extractable organic matter as indicators of litter decomposition in forest soils, J. Plant Nutr. Soil Sci., 169, 76-82, 2006.

Leinweber, P., Schulten, H. R., and Körschens, M.: Hot water extracted organic matter: chemical composition and temporal variations in a long-term field experiment, Biol. Fert. Soils, 20, 17-23, 1995.

Leinweber, P. and Schulten, H. R.: Nonhydrolyzable forms of soil organic nitrogen: Extractability and composition, J. Plant Nutr. Soil Sci., 163, 433-439, 2000.

Li, W., Xia, Y., Ti, C., and Yan, X.: Evaluation of biological and chemical nitrogen indices for predicting nitrogen-supplying capacity of paddy soils in the Taihu Lake region, China. Biol. Fert. Soils, 47, 669-678, 2011.

Malley, D. F., Martin, P. D., and Ben-Dor, D.: 26 Analysis of soils, in: Near-Infrared Spectroscopy in Agriculture, edited by: Roberts C. A., Workman J., and Reeves, J. B., ASA, CSSA, and SSSA publishers inc., Madison, Wisconsin, 729-784, 2004.

Martinez, C. E., Jacobson, A. R., and McBride, M. B.: Aging and temperature effects on DOC and elemental release from a metal contaminated soil, Environ. Pollut., 122, 135-143, 2003.

Mikha, M. M., Rice, C. W., and Benjamin, J. G.: Estimating soil mineralizable nitrogen under different management practices, Soil Sci. Soc. Am. J., 70, 1522-1531, 2006.

Nayyar, A., Singh, B., and Singh, Y.: Nitrogen-Supplying Capacity of Soils for Rice and Wheat and Nitrogen Availability Indices in Soils of Northwest India, Comm. Soil Sci. Plant Anal., 37, 961976, 2006.

Nieder, R., Benbi, D. K., and Scherer, H. W.: Fixation and defixation of ammonium in soils: a review, Biol. Fert. Soils, 47, 1-14, 2011.

Nguyen, V. B., Olk, D. C., and Cassman, K. G.: Nitrogen mineralization from humic acid fractions in rice soils depends on degree of humification, Soil Sci. Soc. Am. J., 68, 1278-1284, 2004.

Nommik, H. and Vahtras, K.: Retention and fixation of ammonium and ammonia in soils, in: Agronomy 22: Nitrogen in agricultural soils, edited by: Stevenson, F. J., ASA, CSSA, and SSSA publishers inc., Madison WI, 123-171, 1982.
Olk, D. C, Cassman, K. G., Randall, E. W., Kinchesh, P., Sanger, L. J., and Anderson, J. M.: Changes in chemical properties of organic matter with intensified rice cropping in tropical rice soil, Eur. J. Soil Sci., 47, 293-303, 1996.

Ong, E. S., Cheong, J. S. H., and Goh, D.: Pressurized hot water extraction of bioactive or marker compounds in botanicals and medicinal plant materials, J. Chromatogr. A, 1112, 92-102, 2006.

Ros, G. H.: Predicting soil Nitrogen supply. Relevance of extractable soil organic matter fractions, $\mathrm{Ph} . \mathrm{D}$. thesis Wageningen University, Wageningen, 2012.

Ros, G. H., Temminghoff, E. J. M., and Hoffland, E.: Nitrogen mineralization: a review and meta-analysis of the predictive value of soil tests, Eur. J. Soil Sci., 62, 162-173, 2011.

Sahrawat, K. L.: Nitrogen availability indexes for submerged rice soils, Adv. Agron., 36, 415-451, 1983a.

Sahrawat, K. L.: Mineralization of organic nitrogen under waterlogged conditions in relation to other soil properties of tropical rice soils, Aust. J. Soil Res., 21, 133-138, 1983b.

Sahrawat, K. L.: Organic matter accumulation in submerged soils, Adv. Agron., 81, 169-201, 2004.

Sahrawat, K. L.: Organic matter and mineralizable nitrogen relationships in wetland rice soils, Comm. Soil Sci. Plant Anal., 37, 787-796, 2006.

Sahrawat, K. L.: Nitrogen mineralization in lowland rice soils: the role of organic matter quantity and quality, Arch. Agron. Soil Sci., 56, 337-353, 2010.

Sahrawat, K. L. and Narteh, L. T.: A chemical index for predicting ammonium production in submerged rice soils, Comm. Soil Sci. Plant Anal., 34, 1013-1021, 2003.

Scherer, H. W.and Zhang, Y. S.: Studies on the mechanism of fixation and release of ammonium in paddy soils after flooding. I. Effect of iron oxides on ammonium fixation. J. Plant Nutr. Soil Sci., 162, 593-597, 1999.

Schneiders, M. and Scherer, H. W.: Fixation and release of ammonium in flooded rice soils as affected by redox potential, Eur. J. Agron., 8, 181-189, 1998.

Schnitzer, M., Schulten, H. R., Schluppi, P., and Angers, D. A.: Organic matter extraction from soils with water at high pressure and temperatures, Soil Sci. Soc. Am. J., 55, 102-108, 1991.

Schulten, H. R. and Leinweber, P.: Thermal stability and composition of mineral-bound organic matter in density fractions of soil, Eur. J. Soil Sci., 50, 237-248, 1999.

Schulten, H. R. and Schnitzer, M.: Chemical model structures for soil organic matter and soils, Soil Sci., 162, 115-130, 1997.

Schulten, H. R. and Schnitzer, M.: The chemistry of soil organic nitrogen: a review, Biol. Fert. Soils, 26, 1-15, 1998.

Silva, J. A. and Bremner, J. M.: Determination and isotope-ratio analysis of different forms of nitrogen in soils: 5. Fixed ammonium, Soil Sci. Soc. Am. J., 30, 587-594, 1966.

Six, J., Elliott, E. T., and Paustian, K.: Soil macroaggregate turnover and microaggregate formation: a mechanism for $\mathrm{C}$ sequestration under no-tillage agriculture, Soil Biol. Biochem., 32, 2099-2103, 2000.

Sleutel, S., Bouckaert, L., Buchan, D., Van Loo D., Cornelis, W. M., and Sanga, H. M.: Manipulation of the soil pore and microbial community structure in soil mesocosm incubation studies, Soil Biol. Biochem., 45, 40-48, 2011. 
Sparling, G., Vojvodic-Vukovic, M., and Schipper, L. A.: Hotwater-soluble $\mathrm{C}$ as a simple measure of labile soil organic matter: The relationship with microbial biomass C, Soil Biol. Biochem., 30, 1469-1472, 1998.

Wilson, C. E., Norman, R. J., Wells, B. R., and Correll, M. D.: Chemical estimation of nitrogen mineralization in paddy rice soils: II. Comparison to greenhouse availability indices, Comm. Soil Sci. Plant Anal., 25, 591-604, 1994.
Wohlfarth, C.: Static dielectric constants of pure liquids and binary liquid mixtures. Landolt-Börnstein: Numerical Data and Functional Relationships in Science and Technology (New Series), Group 4, Macroscopic and Technical Properties of Matter. Vol. 6, Springer-Verlag, Berlin, 1991.

Yonebayashi, K. and Hattori, T.: Patterns and factors controlling nitrogen mineralization in paddy soils in tropical and temperate regions, J. Soil Sci. Plant Nutr., 32, 407-420, 1986.

Zhang, L., Leboeuf, E. J., and Xing, B.: Thermal analytical investigation of biopolymers and humic- and carbonaceous-based soil and sediment organic matter, Environ. Sci. Technol., 41, 48884894, 2007. 